\section{Prevalence of some deteriorating microorganisms in raw milk and some locally made cheese}

\author{
SallyS. Galaby ${ }^{1 *}$, Nagah M. Maharik ${ }^{1}$ and Marwa I. Khalefa ${ }^{2}$ \\ ${ }^{1}$ Department of food hygiene, Faculty of Veterinary \\ Medicine, Assiut University, Assiut, Egypt. \\ ${ }^{2}$ Department of food hygiene, Faculty of Veterinary \\ Medicine, Aswan University, Aswan, Egypt.
}

* Corresponding Author

Sally S. Galaby, Department of food hygiene, Faculty of Veterinary Medicine, Assiut University, Assiut, Egypt. E-mail: Sallysandoz@yahoo.com

Submitted 10/16/2021

Accepted 11/11/2021

\begin{abstract}
Food deterioration has become a very important issue as excessive amounts of food are lost due to microbial spoilage. The work aimed to assess the microbiological quality of raw milk and soft locally made cheeses in Assiut city, Egypt. A total of one hundred and fifty random samples of raw bovine milk (90 samples) and locally made cheese including Kareish and Domiati cheese (30 samples each) were collected randomly from different localities in Assiut city, Egypt. These samples were examined for microbiological evaluation. The investigation revealed that the average $A P C$ were $1.9 \times 10^{6}, 2.6 \times 10^{6}, 6.2 \times 10^{6}, 7.5 \times 10^{5}$ and $1.8 \times 10^{5} \mathrm{cfu} / \mathrm{ml}$ or $/ \mathrm{g}$ for dairy farm milk, dairy shops, street vendor raw milk, Kareish cheese and Domiati cheese, respectively and the average Psychrotrophic count was $8.3 \times 10^{5}, 1.0 \times 10^{6}, 1.5 \times 10^{6}$, $2.5 \times 10^{5}$ and $9.0 \times 10^{4} \mathrm{cfu} / \mathrm{ml}$ or $/ \mathrm{g}$ while the average Proteolytic count was $1.6 \times 10^{5}, 2.1 \times 10^{5}, 3.7 \times 10^{5}, 5.3 \times 10^{4}$ and $2.0 \times 10^{4} \mathrm{cfu} / \mathrm{ml}$ or $/ \mathrm{g}$. Additionally, the average Lipolytic count was $2.5 \times 10^{5}, 3.9 \times 10^{5}, 6.5 \times 10^{5}, 9.8 \times 10^{4}$ and $2.8 \times 10^{4}$ $\mathrm{cfu} / \mathrm{ml}$ or $/ \mathrm{g}$ for the above-mentioned samples respectively. On the other hand, the Lactobacillus counts were $5.5 \times 10^{4}$, $8.8 \times 10^{4}, 1.4 \times 10^{5}, 1.9 \times 10^{4}$ and $5.2 \times 10^{3} \mathrm{cfu} / \mathrm{ml}$ or $/ \mathrm{g}$, respectively. The average count of total yeast and molds were $9.5 \times 10^{2}, 2.5 \times 10^{3}, 7.5 \times 10^{3}, 7.5 \times 10^{2}$ and $6.2 \times 10^{2} \mathrm{cfu} / \mathrm{ml}$ or $/ \mathrm{g}$, respectively. In conclusion, the presence of these organisms indicted that the examined samples were of low quality which reflect unhygienic measures during milking, processing, storage, and distribution chain.
\end{abstract}

Keywords: Lipolytic, Proteolytic, Psychrotrophs, Raw milk, Spoilage

\section{Introduction}

Food products are exposed to microbial spoilage during harvest, manufacture, storage, and distribution. Food spoilage threatens human health and leads to enormous economic loss worldwide to both producers (farmers) and consumers where, about $15-25 \%$ of foodstuffs were deteriorated (Deak and Farkas, 2013). Spoilage of food occurs when the quality of food deteriorates from its original organoleptic properties observed at the time of processing. Factors such as storage temperature, $\mathrm{pH}$, water availability, presence of spoilage microorganisms including bacteria and fungi, initial microbial load (total viable count), and processing influence the rate of food spoilage (Odeyemi et al. 2019). Dirty food contact surfaces and poor personal hygiene standards among food handlers are two of the leading sources of microbial contamination and proliferation in food items (WHO, 2007; Jones et al., 2008). They also play an important role in probable cross-contamination because they can be an asymptomatic carrier of foodborne diseasecausing bacteria (Walker et al., 2003). Raw milk provides a highly nutritious habitat that is susceptible to microbial contamination because it contains various macronutrients such as carbohydrates, fats and protein and micronutrients such as vitamins, amino acids, and fatty acids (Quigley et al., 2013). Soft cheese is one of the most appreciated cheeses in the Middle East. Egypt has a long and rich tradition in cheese making based on the many traditional cheese varieties. Kareish cheese is one of the ancient Egyptian fresh white soft 
cheeses, it is consumed largely due to its low price and high nutritive value. It is made mainly at farmers' houses either by acid coagulation of skimmed milk by natural micro flora present in milk or by adding a rennet to the skimmed milk (Mahmoud, 2020). This method exposes the product to contamination with various types of microorganisms. Those organisms may be responsible for food poising or render the product of inferior quality (Todaro et al., 2013). Domiati cheese makes up to $75 \%$ of the cheese produced and consumed in the country (El-Baradei et al., 2007). In Egypt it is made from cow or buffalos' milk or a mixture of them according to the Egyptian cheese-making technology. The product defects depend on the specific species and number of microorganisms involved in pre- and post- processing. Most often, these changes are related to a single undesirable sensory characteristic, smell, flavor, or consistency (SamarŽija et al., 2007). Undesirable microbes that cause spoilage of dairy products include Gram-negative psychrotrophs, coliforms, lactic acid bacteria and yeast $\&$ molds (Kumbhar et al., 2009). Psychrotrophic bacteria like Pseudomonas spp. can produce proteolytic or lipolytic enzymes which degrade components of raw milk leading to failure in flavor and texture (Ribeiro Júnior et al., 2018). In addition to compromising the integrity of the milk constituents, the microbial proteases and lipases are thermo stable and can remain active even after the elimination of the vegetative microorganisms by heat treatments applied to the milk by the industry (SamarŽija et al., 2012; De Oliveira et al., 2015; Baglinière et al., 2017). Prolonged action of proteases and lipases may cause organoleptic changes in fluid milk or dairy products, such as a bitter or rancid taste in cheeses (Fairbairn and Law, 1986; Matéos et al., 2015 and Zhang et al., 2015). Contamination of milk and dairy products by yeasts or molds results in food spoilage. Due to the ability of yeasts to tolerate the low $\mathrm{pH}$, high osmotic condition, and low refrigeration temperatures, they can cause spoilage and changes in organoleptic, physical, and chemical properties of foods (Arias et al., 2002). Moreover, mold growth on cheese causes economic losses from discoloration, poor appearance, and flavor. In addition, some molds can produce mycotoxins such as aflatoxins which are known carcinogenic (El-Diasty and Salem, 2007). As microbiological analysis is critical for the assessment of quality and safety, confirmation with standards and specifications and regulatory compliance (Vasavada, 1993), total bacterial count indicates the farm general hygienic condition, herd health status, milking equipment sanitation and milk storage temperature (Hayes et al., 2001).

\section{Materials and Methods}

\section{Collection of samples:}

A total of 150 samples of raw milk from dairy farms, local stores, and street vendors (30 samples each) and white soft cheese (Kareish and Domiati) (30 samples each) were collected from local retails, supermarkets, and dairy shops in Assiut city, Egypt. Each sample was obtained in its container as sold to the public.

\section{Preparation of samples and serial dilution (A.P.H.A., 1992):}

\section{A- Raw milk samples:}

Detection of heat-treated milk:

Each milk sample was thoroughly mixed by inversion several times and tested for heat treatment using Storch's test (Lampert, 1975). Then $10 \mathrm{ml}$ milk and two drops of diluted hydrogen peroxide solution (1 part of $\mathrm{H}_{2} \mathrm{O}_{2}, 14$ parts of water and $0.1 \% \mathrm{H}_{2} \mathrm{SO}_{4}$ by volume) were mixed before the addition of two drops of a freshly prepared aqueous solution of paraphenylenediamine $2 \%$. The content was thoroughly mixed, immediate appearance of indigo blue color indicated that milk is raw and heat-treated milk was excluded. $10 \mathrm{ml}$ of the sample were aseptically weighted then added to $90 \mathrm{ml}$ of $0.1 \%$ sterile peptone water to obtain tenfold serial dilution.

\section{B-Soft cheese samples:}

$10 \mathrm{~g}$ of cheese samples were homogenized with $90 \mathrm{ml}$ of $2 \%$ sterilized sodium citrate solution in sterile blender for 2 minutes. Additional tenfold serial dilution was prepared with the same diluent and appropriate dilution was used to enumerate the different groups of microorganisms.

\section{Microbiological Examination:}

A- Total Bacterial Count (TBC) (A.P.H.A., 1992):

One $\mathrm{ml}$ from each dilution was carefully transferred and evenly distributed over duplicated labeled sterile Petri dishes of a dry surface of Standard Plate Count 
(SPC) agar prepared by pouring $12-15 \mathrm{ml}$ of liquefied SPCA at $44-46^{\circ} \mathrm{c}$. Inoculated plates were inverted and incubated at $33 \pm 1^{\circ} \mathrm{c}$ for 48 hours. Plates with $30-300$ colonies were counted.

B-Enumeration of Psychrotrophic bacteria (A.P.H.A.,1992):

One $\mathrm{ml}$ from previously prepared dilution was placed in duplicated plates using standard plate count agar (SPCA). The inoculated plates were incubated at $7^{\circ} \mathrm{C}$ for 10 days.

\section{C- Proteolytic count (A.P.H.A., 1992):}

One $\mathrm{ml}$ from each prepared dilutions was mixed by pouring technique in duplicated plates with $10-15 \mathrm{ml}$ of (SPCA) fortified with $10 \%$ sterile skim milk and incubated at $32^{\circ} \mathrm{c}$ for 2 days.

\section{D- Lipolytic count (A.P.H.A.,1992):}

One $\mathrm{ml}$ from each prepared dilutions was mixed by pouring technique in duplicated plates with $10-15 \mathrm{ml}$ of (SPCA) supplied with Tributyrin followed by incubation for 2 days at $32^{\circ} \mathrm{c}$.

\section{E- Lactose fermenting MOs count (García-Cano et al 2019):}

One $\mathrm{ml}$ from each prepared dilutions was mixed by pouring technique in duplicated plates with $10-15 \mathrm{ml}$ of MRS agar (Man Regosa Sharp agar) with bromocresol green $(0.0025 \%)$ as a $\mathrm{pH}$ indicator. Then the plates were incubated for $24-48$ hours at $37^{\circ} \mathrm{c}$ under anaerobic conditions. Colonies were selected based on phenotypic features such as circular creamy texture white, gray, or green color.

\section{F- Yeast and Mold Count (A.P.H.A., 1985):}

One $\mathrm{ml}$ from each prepared dilution was mixed by pouring technique in duplicated plates with $10-15 \mathrm{ml}$ of Sabouraud dextrose agar (SDA) containing $50 \mathrm{mg}$ of chloramphenicol per liter tempered at $45^{\circ} \mathrm{c}$. After solidification, the inoculated plates were incubated at $25^{\circ} \mathrm{c}$ for 5 days.

\section{Statistical analysis:}

SPSS Pocket program was used for Statistical analysis, values of different parameters were then tabulated.

\section{Results}

Results were tabulated and statistically analyzed as follow:

Table 1: Statistical analytical results of the examined varieties of raw bovine milk and locally made soft cheeses samples based on their Aerobic plate count.

\begin{tabular}{|c|c|c|c|c|c|c|}
\hline \multirow[t]{2}{*}{ Product } & \multirow{2}{*}{$\begin{array}{c}\text { No. of } \\
\text { examined } \\
\text { samples }\end{array}$} & \multicolumn{2}{|c|}{$\begin{array}{l}\text { Positive } \\
\text { Samples }\end{array}$} & \multirow[t]{2}{*}{ Min. } & \multirow[t]{2}{*}{ Max. } & \multirow[t]{2}{*}{ Average } \\
\hline & & No. & $\%$ & & & \\
\hline $\begin{array}{l}\text { Farm } \\
\text { milk }\end{array}$ & 30 & 30 & 100 & $2.5 \times 10^{4}$ & $9 \times 10^{6}$ & $1.9 \times 10^{6}$ \\
\hline $\begin{array}{l}\text { Dairy } \\
\text { shops }\end{array}$ & 30 & 30 & 100 & $3.3 \times 10^{4}$ & $1.4 \times 10^{7}$ & $2.6 \times 10^{6}$ \\
\hline $\begin{array}{l}\text { Street } \\
\text { vendors }\end{array}$ & 30 & 30 & 100 & $5.8 \times 10^{4}$ & $3.3 \times 10^{7}$ & $6.2 \times 10^{6}$ \\
\hline $\begin{array}{l}\text { Kareish } \\
\text { cheese }\end{array}$ & 30 & 30 & 100 & $1.3 \times 10^{4}$ & $5.2 \times 10^{6}$ & $7.5 \times 10^{5}$ \\
\hline $\begin{array}{l}\text { Domiati } \\
\text { cheese }\end{array}$ & 30 & 30 & 100 & $6.1 \times 10^{3}$ & $1.1 \times 10^{6}$ & $1.8 \times 10^{5}$ \\
\hline
\end{tabular}

Table 2: Statistical analytical results of the examined varieties of raw bovine milk and locally made soft cheeses samples based on their Psychrotrophic count.

\begin{tabular}{|c|c|c|c|c|c|c|}
\hline & \multirow{2}{*}{$\begin{array}{c}\text { No. of } \\
\text { examined } \\
\text { Product }\end{array}$} & \multicolumn{2}{|c|}{$\begin{array}{c}\text { Positive } \\
\text { Samples }\end{array}$} & \multirow{2}{*}{ Min. } & Max. & Average \\
\cline { 3 - 4 } & No. & $\%$ & & & \\
\hline $\begin{array}{c}\text { Farm } \\
\text { Milk }\end{array}$ & 30 & 30 & 100 & $6.2 \times 10^{3}$ & $5.4 \times 10^{6}$ & $8.3 \times 10^{5}$ \\
\hline $\begin{array}{c}\text { Dairy } \\
\text { shops }\end{array}$ & 30 & 30 & 100 & $5.9 \times 10^{3}$ & $6.3 \times 10^{6}$ & $1.0 \times 10^{6}$ \\
\hline $\begin{array}{c}\text { Street } \\
\text { vendors }\end{array}$ & 30 & 30 & 100 & $1.2 \times 10^{3}$ & $6.5 \times 10^{6}$ & $1.5 \times 10^{6}$ \\
\hline $\begin{array}{c}\text { Kareish } \\
\text { cheese }\end{array}$ & 30 & 30 & 100 & $3.6 \times 10^{3}$ & $2.2 \times 10^{6}$ & $2.5 \times 10^{5}$ \\
\hline $\begin{array}{c}\text { Domiati } \\
\text { cheese }\end{array}$ & 30 & 30 & 100 & $2.8 \times 10^{3}$ & $7.7 \times 10^{5}$ & $9.0 \times 10^{4}$ \\
\hline
\end{tabular}

Table 3: Statistical analytical results of the examined varieties of raw bovine milk and locally made soft cheese samples based on their Proteolytic count.

\begin{tabular}{|c|c|c|c|c|c|c|}
\hline \multirow[t]{2}{*}{ Product } & \multirow{2}{*}{$\begin{array}{c}\text { No. of } \\
\text { examined } \\
\text { samples }\end{array}$} & \multicolumn{2}{|c|}{$\begin{array}{l}\text { Positive } \\
\text { Samples }\end{array}$} & \multirow[t]{2}{*}{ Min. } & \multirow[t]{2}{*}{ Max. } & \multirow[t]{2}{*}{ Average } \\
\hline & & No. & $\%$ & & & \\
\hline $\begin{array}{c}\text { Farm } \\
\text { milk }\end{array}$ & 30 & 30 & 100 & $1.5 \times 10^{3}$ & $8.5 \times 10^{5}$ & $1.6 \times 10^{5}$ \\
\hline $\begin{array}{l}\text { Dairy } \\
\text { shops }\end{array}$ & 30 & 30 & 100 & $2.1 \times 10^{3}$ & $1.1 \times 10^{6}$ & $2.1 \times 10^{5}$ \\
\hline $\begin{array}{c}\text { Street } \\
\text { vendors }\end{array}$ & 30 & 30 & 100 & $3.8 \times 10^{3}$ & $3.2 \times 10^{6}$ & $3.7 \times 10^{5}$ \\
\hline $\begin{array}{l}\text { Kareish } \\
\text { cheese }\end{array}$ & 30 & 30 & 100 & $1.0 \times 10^{3}$ & $5.4 \times 10^{5}$ & $5.3 \times 10^{4}$ \\
\hline $\begin{array}{l}\text { Domiati } \\
\text { cheese }\end{array}$ & 30 & 30 & 100 & $1.0 \times 10^{3}$ & $1.2 \times 10^{5}$ & $2.0 \times 10^{4}$ \\
\hline
\end{tabular}

Table 4: Statistical analytical results of the examined varieties of raw bovine milk and locally made soft cheeses samples based on their Lipolytic count.

\begin{tabular}{|l|c|c|c|c|c|c|}
\hline \multirow{2}{*}{ Product } & \multirow{2}{*}{$\begin{array}{c}\text { No. of } \\
\text { examined } \\
\text { samples }\end{array}$} & \multicolumn{2}{|c|}{$\begin{array}{c}\text { Positive } \\
\text { samples }\end{array}$} & Min. & Max. & Average \\
\cline { 3 - 4 } $\begin{array}{l}\text { Farm } \\
\text { Milk }\end{array}$ & 30 & 30 & 100 & $4.0 \times 10^{3}$ & $1.5 \times 10^{6}$ & $2.5 \times 10^{5}$ \\
\hline $\begin{array}{l}\text { Dairy } \\
\text { shops }\end{array}$ & 30 & 30 & 100 & $5.3 \times 10^{3}$ & $2.5 \times 10^{6}$ & $3.9 \times 10^{5}$ \\
\hline $\begin{array}{l}\text { Street } \\
\text { vendors }\end{array}$ & 30 & 30 & 100 & $7.1 \times 10^{3}$ & $4.2 \times 10^{6}$ & $6.5 \times 10^{5}$ \\
\hline $\begin{array}{l}\text { Kareish } \\
\text { cheese }\end{array}$ & 30 & 30 & 100 & $1.8 \times 10^{3}$ & $6.9 \times 10^{5}$ & $9.8 \times 10^{4}$ \\
\hline $\begin{array}{l}\text { Domiati } \\
\text { cheese }\end{array}$ & 30 & 30 & 100 & $1.7 \times 10^{3}$ & $1.7 \times 10^{5}$ & $2.8 \times 10^{4}$ \\
\hline
\end{tabular}


Table 5: Statistical analytical results of the examined varieties of raw bovine milk and locally made soft cheeses samples based on their Lactobacillus count.

\begin{tabular}{|c|c|c|c|c|c|c|}
\hline \multirow[t]{2}{*}{ Product } & \multirow{2}{*}{$\begin{array}{c}\text { No. of } \\
\text { examined } \\
\text { samples }\end{array}$} & \multicolumn{2}{|c|}{$\begin{array}{l}\text { Positive } \\
\text { Samples }\end{array}$} & \multirow[t]{2}{*}{ Min. } & \multirow[t]{2}{*}{ Max. } & \multirow[t]{2}{*}{ Average } \\
\hline & & No. & $\%$ & & & \\
\hline $\begin{array}{l}\text { Farm } \\
\text { milk }\end{array}$ & 30 & 30 & 100 & $1.0 \times 10^{3}$ & $3.4 \times 10^{5}$ & $5.5 \times 10^{4}$ \\
\hline $\begin{array}{l}\text { Dairy } \\
\text { shops }\end{array}$ & 30 & 30 & 100 & $1.0 \times 10^{3}$ & $5.1 \times 10^{5}$ & $8.8 \times 10^{4}$ \\
\hline $\begin{array}{l}\text { Street } \\
\text { vendors }\end{array}$ & 30 & 30 & 100 & $1.8 \times 10^{3}$ & $6.7 \times 10^{5}$ & $1.4 \times 10^{5}$ \\
\hline $\begin{array}{l}\begin{array}{l}\text { Kareish } \\
\text { cheese }\end{array} \\
\end{array}$ & 30 & 30 & 100 & $1.0 \times 10^{3}$ & $9.7 \times 10^{4}$ & $1.9 \times 10^{4}$ \\
\hline $\begin{array}{l}\text { Domiati } \\
\text { cheese }\end{array}$ & 30 & 30 & 100 & $4.0 \times 10^{2}$ & $2.4 \times 10^{4}$ & $5.2 \times 10^{3}$ \\
\hline
\end{tabular}

Table 6: Statistical analytical results of the examined varieties of raw bovine milk samples based on their total yeasts \& molds count.

\begin{tabular}{|c|c|c|c|c|c|c|}
\hline \multirow[t]{2}{*}{ Product } & \multirow{2}{*}{$\begin{array}{c}\text { No. of } \\
\text { examined } \\
\text { samples }\end{array}$} & \multicolumn{2}{|c|}{$\begin{array}{l}\text { Positive } \\
\text { Samples }\end{array}$} & \multirow[t]{2}{*}{ Min. } & \multirow[t]{2}{*}{ Max. } & \multirow[t]{2}{*}{ Average } \\
\hline & & No. & $\%$ & & & \\
\hline $\begin{array}{l}\text { Farm } \\
\text { milk }\end{array}$ & 30 & 27 & 90 & $1.0 \times 10^{2}$ & $3.9 \times 10^{3}$ & $9.5 \times 10^{2}$ \\
\hline $\begin{array}{l}\text { Dairy } \\
\text { shops }\end{array}$ & 30 & 30 & 100 & $3.0 \times 10^{2}$ & $9.5 \times 10^{3}$ & $2.5 \times 10^{3}$ \\
\hline $\begin{array}{l}\text { Street } \\
\text { vendors }\end{array}$ & 30 & 30 & 100 & $6.0 \times 10^{2}$ & $4.7 \times 10^{4}$ & $7.5 \times 10^{3}$ \\
\hline $\begin{array}{l}\text { Kareish } \\
\text { cheese }\end{array}$ & 30 & 25 & 83 & $1.0 \times 10^{2}$ & $1.9 \times 10^{3}$ & $7.5 \times 10^{2}$ \\
\hline $\begin{array}{l}\text { Domiati } \\
\text { cheese }\end{array}$ & 30 & 22 & 73 & $1.0 \times 10^{2}$ & $2.2 \times 10^{3}$ & $6.2 \times 10^{2}$ \\
\hline
\end{tabular}

Table 7: Quality of local made cheese samples for total yeast and mold count according to the (Egyptian Standards, 2005).

\begin{tabular}{|c|c|c|c|c|c|}
\hline \multirow{2}{*}{ Product } & \multirow{2}{*}{$\begin{array}{l}\text { Permissible } \\
\text { limit of total } \\
\text { yeast and } \\
\text { mold }\end{array}$} & \multicolumn{2}{|c|}{$\begin{array}{l}\text { Acceptable } \\
\text { samples }\end{array}$} & \multicolumn{2}{|c|}{$\begin{array}{c}\text { Unacceptable } \\
\text { samples }\end{array}$} \\
\hline & & No. & $\%$ & No. & $\%$ \\
\hline $\begin{array}{l}\text { Kareish } \\
\text { cheese }\end{array}$ & \multirow{2}{*}{$\begin{array}{l}\text { Not more } \\
\text { than } 410 \\
\text { CFU/g }\end{array}$} & 4 & 13 & 26 & 87 \\
\hline $\begin{array}{l}\text { Domiati } \\
\text { cheese }\end{array}$ & & 8 & 27 & 22 & 73 \\
\hline
\end{tabular}

\section{Discussion}

Results recorded in Table 1 revealed that the APC of raw milk collected from dairy farms ranged from $2.5 \times 10^{4}$ to $9 \times 10^{6} \mathrm{cfu} / \mathrm{ml}$ with an average value of $1.9 \times$ $10^{6} \mathrm{cfu} / \mathrm{ml}$. Higher APC was revealed from dairy shops samples and ranged from $3.3 \times 10^{4}$ to $1.4 \times 10^{7}$ $\mathrm{cfu} / \mathrm{ml}$ with an average of $2.6 \times 10^{6} \mathrm{cfu} / \mathrm{ml}$. As well as the street vendors raw milk samples ranged from $5.8 \times 10^{4}$ to $3.3 \times 10^{7} \mathrm{cfu} / \mathrm{ml}$ with an average value $6.2 \times 10^{6} \mathrm{cfu} / \mathrm{ml}$, unlike to lower results obtained by Ercolini et al. (2009).
Total counts of bacteria are the most useful indication of the microbiological status of dairy products. High levels indicate raw material contamination, improper sanitation or unsuitable time and temperature factors during storage and production (Mossel, 1983).

Realizing the data outlined in Table 2, it was evident that raw milk samples collected from dairy farms, dairy shops and street vendors had an average count $8.3 \times 10^{5}, 1.0 \times 10^{6}$ and $1.5 \times 10^{6} \mathrm{cfu} / \mathrm{ml}$, respectively with minimum values of $6.2 \times 10^{3}, 5.9 \times 10^{3}$ and $1.2 \times 10^{3}$ $\mathrm{cfu} / \mathrm{ml}$ and maximum count of $5.4 \times 10^{6}, 6.3 \times 10^{6}$ and $6.5 \times 10^{6} \mathrm{cfu} / \mathrm{ml}$, respectively. These obtained results were higher than that reported by Hantsis-Zacharov and Halpern (2017) and Ribeiro Junior et al. (2018).

These findings could be attributed to the presence of psychrotrophs being related to poor hygiene and food spoilage as these organisms were well adapted to cold temperatures and showed enzymatic activity at $4^{\circ} \mathrm{c}$.

As noticed from the findings in Table 3 the minimum, maximum and average values of proteolytic counts of dairy farm raw milk samples were $1.5 \times 10^{3}, 8.5 \times 10^{5}$ and $1.6 \times 10^{5} \mathrm{cfu} / \mathrm{ml}$, respectively while in dairy shops samples were $2.1 \times 10^{3}, 1.1 \times 10^{6}$ and $2.1 \times 10^{5} \mathrm{cfu} / \mathrm{ml}$, respectively. As well as in street vendor samples were $3.8 \times 10^{3}, 3.2 \times 10^{6}$ and $3.7 \times 10^{5} \mathrm{cfu} / \mathrm{ml}$, respectively.

The summarized results in Table 4 demonstrated that the minimum, maximum and average values of lipolytic counts of dairy farm raw milk samples were $4.0 \times 10^{3}, 1.5 \times 10^{6}$ and $2.5 \times 10^{5} \mathrm{cfu} / \mathrm{ml}$, respectively while in dairy shops milk were $5.3 \times 10^{3}, 2.5 \times 106$ and $3.9 \times 10^{5} \mathrm{cfu} / \mathrm{ml}$ as well as in street vendors samples were $7.1 \times 10^{3}, \quad 4.2 \times 10^{6}$ and $6.5 \times 10^{5} \mathrm{cfu} / \mathrm{ml}$, respectively.

It was obvious that the heavy contamination of all samples especially street vendor raw milk may be due to contamination during milking and unsanitary storage, handling, and packaging.

Data obtained in Table 5 pinpointed that the average lactobacillus count of farm milk, dairy shops and street vendor milk samples were $5.5 \times 10^{4}, 8.8 \times 10^{4}$ and $1.4 \times 10^{5} \mathrm{cfu} / \mathrm{ml}$ with counts ranging from $1.0 \times 10^{3}$ to $3.4 \times 10^{5} \mathrm{cfu} / \mathrm{ml}$, from $1.0 \times 10^{3}$ to $5.1 \times 10^{5} \mathrm{cfu} / \mathrm{ml}$ and from $1.8 \times 10^{3}$ to $6.7 \times 10^{5} \mathrm{cfu} / \mathrm{ml}$ respectively. Higher counts of Lactobacillus were indicated by Stojiljkovic (2018) While, lower values were detected by Quigley et al. (2013). 
It was evident from the result in Table 6 that the average of total yeasts and molds count of farm milk, dairy shops and street vendor milk samples were $9.5 \times 10^{2}, 2.5 \times 10^{3}$ and $7.5 \times 10^{3} \mathrm{cfu} / \mathrm{ml}$ with counts ranging from $1.0 \times 10^{2}$ to $3.9 \times 10^{3} \mathrm{cfu} / \mathrm{ml}$, from $3.0 \times 10^{2}$ to $9.5 \times 10^{3} \mathrm{cfu} / \mathrm{ml}$ and from $6.0 \times 10^{2}$ to $4.7 \times 10^{4} \mathrm{cfu} / \mathrm{ml}$ respectively.

Cheese is considered an essentially microbial fermentation of milk by selected lactic acid bacteria whose major function is producing lactic acid from lactose causing curd formation. Kareish cheese is the most popular local types of soft cheese in Egypt, characterized by low-fat content, source of protein, calcium, phosphorus, and water-soluble vitamins (ElBagoury and Mosaad, 2002). While Domiati cheese makes up about $75 \%$ of the cheese produced and consumed in Egypt (El-Baradei et al., 2007).

The afore mentioned data in Table 1 concluded that the minimum and maximum values of total aerobic plate count of both Kareish and Domiati cheese were $1.3 \times 10^{4}, 6.1 \times 10^{3} \mathrm{cfu} / \mathrm{g}$ and $5.2 \times 10^{6}, 1.1 \times 10^{6} \mathrm{cfu} / \mathrm{g}$. While the average values were $7.5 \times 105$ and $1.8 \times 10^{5}$ $\mathrm{cfu} / \mathrm{g}$, respectively. Higher results were obtained by Aly and Galal (2002) and Sayed et al. (2011) in Domiati cheese, Abd Alla (2004) in Kareish cheese and El-Bessary (2006) in both types. While lower counts were detected by Ali (2005) and Wafy (2006).

These obtained results reflected the bad sanitary condition of the locally made soft cheese where Kareish cheese was made by small-holders and sold at local markets uncovered and without suitable containers. So, it was exposed to contamination with several types of microorganisms and a good medium for the growth of spoilage and deteriorating microorganisms.

The microbiological quality of Domiati cheese can be affected by many factors as: the quality of raw milk, thermal treatment of the milk and levels and types of microbial contamination which occur during manufacture and storage.

Regarding Table 2, the minimum and maximum values of the psychrotrophic count of both Kareish and Domiati cheese were $3.6 \times 10^{3}, 2.8 \times 10^{3} \mathrm{cfu} / \mathrm{g}$ and $2.2 \times 10^{6}, 7.7 \times 10^{5} \mathrm{cfu} / \mathrm{g}$. While the average values were $2.5 \times 10^{5}$ and $9.0 \times 10^{4} \mathrm{cfu} / \mathrm{g}$, respectively.

The relatively high results obtained in this study could be concluded to the ability of psychrotrophic to form hydrolytic enzymes causing spoilage to raw milk and dairy products constituents as fat and protein when stored in the refrigerator. This leads to losses of the modern dairy industry as up to $30 \%$ because of spoilage and reduced product quality.

The results recorded in Table 3 pinpointed that the minimum, maximum and average proteolytic count in Kareish cheese samples were $1.0 \times 10^{3}, 5.4 \times 10^{5}$ and $5.3 \times 10^{4} \mathrm{cfu} / \mathrm{g}$, respectively. Besides that, the proteolytic count in Domiati cheese samples was ranged from $1.0 \times 10^{3}$ to $1.2 \times 10^{5} \mathrm{cfu} / \mathrm{g}$ with an average count of $2.0 \times 10^{4} \mathrm{cfu} / \mathrm{g}$. These findings were far lower than detected by Hassan et al. (2019).

These proteolytic microorganisms result in the decomposition of protein content due to the proteolysis process and leads to microorganisms' development.

Data summarized in Table 4 declared that minimum, maximum and average lipolytic count in Kareish cheese samples were $1.8 \times 10^{3}, 6.9 \times 10^{5}$ and $9.8 \times 10^{4}$ $\mathrm{cfu} / \mathrm{g}$, respectively. Also, it was clear that the lipolytic count in Domiati cheese samples was ranged from $1.7 \times 10^{3}$ to $1.7 \times 10^{5} \mathrm{cfu} / \mathrm{g}$ with an average count of $2.8 \times 10^{4} \mathrm{cfu} / \mathrm{g}$.

It was evident from the results in both Table 5 that the examined Kareish cheese had counts ranging from $1.0 \times 10^{3}$ to $9.7 \times 10^{4} \mathrm{cfu} / \mathrm{g}$ with an average count $1.9 \times 10^{4} \mathrm{cfu} / \mathrm{g}$. The minimum, maximum and average lactobacillus counts of Domiati cheese were $4.0 \times 10^{2}$, $2.4 \times 10^{4}$ and $5.2 \times 10^{3} \mathrm{cfu} / \mathrm{g}$, respectively.

Yeasts and molds could be detected in $83 \%$ of the Kareish cheese and $73 \%$ of Domiati cheese samples with average value $7.5 \times 10^{2}$ and $6.2 \times 10^{2} \mathrm{cfu} / \mathrm{g}$ and counts ranging from $1.0 \times 10^{2}$ to $1.9 \times 10^{3} \mathrm{cfu} / \mathrm{g}$ for Kareish cheese and from $1.0 \times 10^{2}$ to $2.2 \times 10^{3} \mathrm{cfu} / \mathrm{g}$ for Domiati cheese samples, respectively as shown in Table 6 . As well as Table 7 revealed that only $13 \%$ and $27 \%$ of Kareish and Domiati cheese were acceptable samples according to Egyptian Standards (2005) while all other samples were unacceptable.

The contamination of these products may occur from using raw material or during manufacture, storage, and distribution. Spoilage of cheeses by yeast appears as visible growth of yeast colonies on the surface of cheese, unpleasant smell, or taste, change in texture and deformation of the packets. Their occurrence in Domiati cheese may be attributed to the yeast's ability to grow at low temperature, the assimilation of organic acids like lactic and citric acid, their proteolytic 
impolitic activities, resistance against high salt concentration and resistance to cleaning compounds and sanitizers. The main defects caused by yeasts are fruity, bitter, or yeasty off flavors, discoloration changes and texture.

Additionally, molds contamination not only cause deterioration of the foods but also adversely affect the health of both animal and human. Molds can form toxins (Mycotoxins) which may induce food poising and neoplastic diseases as leukemia among customers.

\section{Conclusion}

In conclusion, the microbiological evaluation of the examined samples indicated that the bacteriological quality was inferior as well as unacceptable concerning the Egyptian standards for total aerobic count, yeasts, and molds.

The presence of these organisms in high number renders the dairy products unfit for human consumption and through the development of undesirable changes which reflect unhygienic measures, inadequate heat treatment during the manufacture, using bad quality ingredients or additives and improper sanitation during storage, handling, and distribution.

\section{Conflict of interest}

The authors declared no conflict of interest.

\section{References}

Abd Alla, A.M.K. (2004): Chemical and microbiological studies on some homemade dairy products. M.Sc. Thesis, Fac. Agric., Assiut Univ., Egypt.

Aly, S.A. and Galal, E.A. (2002): Effect of milk pretreatment on the keeping quality of Domiati cheese. Pakistan Journal of Nutrition, 1(3): 132-136.

Ali, M. M. (2005): Studies on microbiological status of local and imported processed (smoked) cheese. J. Egypt Vet. Med. Assoc. 65:45.

A.P.H.A. (American Public health association) (1985): Standard Methods for the Examination of Dairy Products. 15th ed., American, Richardson, G.H. Washington D.C.

A.P.H.A. (1992): Standard Methods for the Examination of Dairy Products. 16th ed., American Public Health Association, Washington. D.C., USA.
Arias, C.R.; Burns, J.K.; Friedrich, L.M.; Goodrich, R.M. and Parish, M.E. (2002): Yeast species associated with orange juice: Evaluation of different identification methods. Appl. Environ. Microbiol., 68 (4):1955-1961.

Baglinière, F.; J. Jardin, J.; Gaucheron, F.; De Carvalho, A.F. and Vanetti, M. C. D. (2017): Proteolysis of casein micelles by heat-stable protease secreted by Serratia liquefaciens leads to the destabilization of UHT milk during its storage. Int. Dairy J., 68: 38-45.

Deak, T. and Farkas, J. (2013): Microbiology of thermally preserved foods, canning and novel physical methods. DEStech Publication, Pennsylvania.

De Oliveira, G.B.; Favarin, L.; Luchese, R.H. and Mclntosh, D. (2015): Psychrotrophic bacteria in milk: How much do we really know? Braz. J. Microbiol., 46 (2): 313-321.

El-Bagoury, A. and Mosaad, A.A. (2002): Incidence of Salmonella and Escherichia coli in Kareish cheese with special reference to heat stable enterotoxin producing Escherichia coli using polymerase chain reaction. Minufia Vet. J., 2 (1):59-66.

El-Baradei, G.; Delacroix- Buchet, A. and Ogier, J. (2007): Biodiversity of bacterial ecosystems in traditional Egyptian Domiati cheese. Appl. Environ. Microbiol., 73 (4): 1248 - 1255.

El-Bessary, M.M. (2006): Sanitary status of milk and some milk products marketed in suburbs of Assiut governorate. Ph.D. Thesis, Fac. Vet. Med., Assiut Univ., Egypt.

El-Diasty, E.M. and Salem, R.M. (2007): Incidence of lipolytic and proteolytic fungi in some milk products and their public health significance. J. Appl. Sci. Res., 3(12): 1684-1688.

ES (Egyptian Standards) No (1008-1185) (2005): Soft cheese. Part 4: Kareish cheese. Egyptian organization for standardization and quality control.

Ercolini, D.; Russo, F.; Ferrocino, I. and Villani, F. (2009): Molecular identification of mesophilic and psychrotrophic bacteria from raw cow's milk. Food Microbiol., 26 (2): 228 - 231.

Fairbairn, D. J. and Law, B. A. (1986): Proteinases of psychrotrophic bacteria: their production, properties, effects, and control. J. Dairy Res., 53:139-177.

García-Cano, I.; Rocha-Mendoza, D.; Ortega-Anaya, J.; Wang, K.; Kosmerl, E. and Jiménez-Flores, R. (2019): Lactic acid bacteria isolated from dairy 
products as potential producers of lipolytic, proteolytic and antibacterial proteins. Appl. Microbiol. Biotechnol.,103: 5243 - 5257.

Hantsis-Zacharov, E. and Halpern, M. (2017): Culturable psychrotrophic bacterial communities in raw milk and their proteolytic and lipolytic traits. Appl. Environ. Microbiol., 73 (22): 7162 - 7168.

Hassan, G.M.; Meshref, A.M.S.; Zeinhom, M.M.A. and Abdel-Halem, M.S. (2019): Impact of spoilage microorganisms on some dairy products. Assiut Vet. Med. J., 65 (161): 133 -141.

Hayes, M.C.; Ralyea, R.D.; Murphy, S.C.; Carey, N.R.; Scarlett, J.M. and Boor, K.J. (2001): Identification and characterization of elevated microbial counts in bulk tank raw milk. J. Dairy Sci., 84(1): 292-298.

Jones, S.L.; Parry, S.M.; O'Brien, S.J. and Palmer, S.R. (2008): Are staff management practices and inspection risk ratings associated with foodborne disease outbreaks in the catering industry in England and Wales? J. Food Prot., 71: 550-557.

Kumbhar, S.B.; Ghosh, J.S. and Samudre, S.P. (2009): Microbiological analysis of pathogenic organisms in indigenous fermented milk products. Adv. J. Food Sci. Technol., 1 (1): 35 - 38.

Lampert, L.M. (1975): Modern Dairy Products. 3rd ed., Chemical Publishing Co., Inc., New York, U.S.A.

Mahmoud, E. O. A. (2020): Quality evaluation of locally manufactured cheese in the New Valley governorate. Ph.D. Thesis, Fac. Vet. Med., Assiut Univ., Egypt.

Matéos, A.; Guyard-Nicodème, M.; Baglinière, F.; Jardin, J.; Gaucheron, F.; Dary, A.; Humbert, G. and Gaillard, J. L (2015): Proteolysis of milk proteins by AprX, an extracellular protease identified in Pseudomonas LBSA1 isolated from bulk raw milk and implications for the stability of UHT milk. Int. Dairy J., 49:78-88.

Mossel, D.A.A. (1983): Essential and preservatives of the microbial ecology of foods. In: Roberts, T.A., Skinner, F.A., Ed., Food Microbiology: advances and prospects, London: Academic Press.

Odeyemi, O. A.; Alegbeleye, O. O.; Strateva, M.; Stratev D. (2019): Understanding spoilage microbial community and spoilage mechanisms in foods of animal origin. Compr. Rev. Food Sci. Food Saf., 19: 311-331.
Quigley, L.; O’Śullivan, O.; Stanton, C.; Beresford, T.B.; Paul Ross, R.; Fitzgerald, G.F. and Cotter, P.D. (2013): The complex microbiota of raw milk. FEMS Microbiol. Rev., 37: 664 - 698.

Ribeiro Júnior, J.C.; De Oliveira, A.M.; De G. Silva, F.; Tamanini, R.; De Oliveira, A.L.M. and Beloti, V. (2018): The main spoilage-related psychrotrophic bacteria in refrigerated raw milk. J. Dairy Sci., 101 (1): 75-83.

SamarŽija, D.; PodoreŠki, M.; Sikora, S.; Skelin, A. and Pogačić, T. (2007): Spoilage microorganisms in milk and dairy products. Mljekarstvo, 57 (4): 251 273.

Samarzija, D.; Zamberlin, S. and Pogaci, C. T. (2012): Psychrotrophic bacteria and milk and dairy products quality. Mljekarstvo 62:77-95.

Stojiljkovic, J. (2018): The count of lactic acid bacteria in white cheese. Agriculture, Forestry and Fisheries, 7 (6): 143-149.

Sayed, M.; Abdel-hameid, A. and Shaban,W. (2011): Microbiological evaluation of some Egyptian white soft cheeses. Benha Vet. Medical J., 1:1 - 6 .

Todaro, A.; Adly, F. A. and Omar, O. A.H. (2013): History, processing, and quality enhancement of traditional Egyptian Kareish cheese. J. Food Sci. \& Technol., 1(1): 1- 6 .

Vasavada, P.C. (1993): Rapid methods and automation in dairy microbiology. J. Dairy Sci., 76 (10): 3101- 3113.

Wafy, Y.M. (2006): Sanitary improvement of serving milk and milk products in Assiut University Hospital. Ph.D. Thesis, Fac. Vet. Med., Assiut Univ. Egypt.

Walker, E.; Pritchard, C. and Forsythe, S. (2003): Food handlers' hygiene knowledge in small food businesses. Food Control, 14(5): 339-343.

WHO, "World Health Organization" (2007): Food safety and food borne illness. Factsheet 237. Available at: www.who.int/mediacentre/factsheet/ fs237/en/ index.html. Accessed 13June 2012.

Zhang, S.; Li, H.; Uluko, H.; Liu, L.; Pang, X. and Lv, J. (2015): Investigation of protease production by Pseudomonas fluorescens BJ-10 and degradation on milk proteins. J. Food Process. Preserv., 39(6): 24662472. 